\title{
Determination of the Environmental Effects of Plant Protection Products in Fighting Pests in Greenhouse Vegetable Production: Batman Province Example
}

\author{
Mehmet Kaplan \\ Faculty of Agriculture, Department of Plant Protection, \\ Siirt University, 56100, Siirt, Turkey \\ E-mail: mehmetkaplan1971@gmail.com, \\ Burak Saltuk (Corresponding author) \\ Alanya Alaaddin Keykubat University, \\ Department of Biosystem Engineering, Alanya/Antalya, Turkey \\ E-mail: bsaltuk@gmail.com
}

\begin{abstract}
This study was carried out to determine the environmental awareness levels of agricultural enterprises in the province of Batman and its districts where greenhouse production was carried out in 2020. With this purpose, and based on simple random sampling method, information was obtained from 75 producers in 15 villages, 5 randomly selected villages from three districts (Central, Besiri, Sason), using a 37-question survey method and the results have been evaluated as a percentage (\%). With this study, it has been determined that the education level of the greenhouse producers is high, most of them have non-agricultural income and the amount of their income is above the hunger limit. Greenhouse producers take advice from vendors and the District Directorate of Agriculture and Forestry to determine pesticide selection and pesticide dosage. They reported that the producers pay attention to important factors in the selection of pesticides like brand and active substance, they do not use the same pesticide against the same disease and pest continuously, they apply the recommended dose before the disease and pest appears, that the pesticides they use leave residues in the product, they pay attention to the waiting time between spraying and harvest, they reported that they use protective clothing and masks, do not throw empty pesticide boxes on the field or roadside, clean the spraying tool, but they said that they have use the spraying tool without calibration and applied pesticides as a mixture. However, it has been determined that they prefer cultural methods in addition to chemical methods and they are not aware of the concept of biopesticide.

Farmers generally prefer chemical warfare methods to overcome plant protection problems, and mistaken pesticide applications bring many negative effects in terms of human and environmental health.
\end{abstract}

Keywords: Greenhouse, Plant Protection Problems, Survey, Batman.

DOI: $10.7176 / \mathrm{JSTR} / 7-06-01$

\section{Introduction}

Turkey has an important potential in terms of agricultural production and agriculture is the main source of the nation's economy. The agricultural areas of Turkey are gradually decreasing year by year due to various reasons such as erosion, population increase and the spread of industrial zones. However, in addition to the inability to open up new agricultural areas, ever-increasing nutritional problems and hunger as well as the gradual decrease in soil fertility due to various reasons, have all made it inevitable to develop strategic policies aimed at obtaining greater efficiency from every inch of agricultural area. For this reason, there has been a significant increase in the production of agricultural products in

1 | $\mathrm{P}$ a g e

www.iiste.org 
greenhouses as an alternative to open areas due to ecological conditions in recent years, and these activities have especially intensified on the southern coasts. According to 2018 data, Turkey's total greenhouse area is 77209.1 ha, 21122.2 ha of it is low tunnel, 11423.2 ha is high tunnel, 36852.7 ha is plastic greenhouse and 7810.1 ha is glass greenhouse [1]. Greenhouse agriculture is one of the most important income-generating branches of agriculture. In the studies conducted by the researcher, it has been concluded that yield and quality would increase if the indoor conditions of greenhouse are controlled. In addition, it has been stated that in winter months, the temperature inside the greenhouse, where humidity and temperature values are prominent, can be reduced by natural ventilation and consequent use of pesticides will decrease. [2, 3]. According to Table 1, the most engaged region in greenhouse cultivation in our country is the Mediterranean region with 656033 da. Aegean region is following with 76223 da, Marmara region is in third place with 15604 da, Black Sea region is fourth with 14578 da, followed by Central Anatolia region with 5633 da, Southeastern Anatolia region with 2244 and finally the Eastern Anatolia region with 1731 [1].

Table 1. Distribution of greenhouse cultivation operations per region in Turkey

\begin{tabular}{c|c|c|c|c|c} 
Region Name & $\begin{array}{c}\text { Low Tunnel } \\
(\mathbf{D a})\end{array}$ & $\begin{array}{c}\text { Glass } \\
\text { Greenhouse } \\
(\mathbf{D a})\end{array}$ & $\begin{array}{c}\text { Plastic } \\
\text { Greenhouse } \\
(\mathbf{D a})\end{array}$ & $\begin{array}{c}\text { High Tunnel } \\
(\mathbf{D a})\end{array}$ & Total (Da) \\
\hline Mediterranean & 203738 & 71372 & 300980 & 79944 & 656033 \\
\hline Aegean & 6196 & 6097 & 49311 & 14619 & 76223 \\
\hline Marmara & 129 & 295 & 7388 & 7792 & 15604 \\
\hline Black Sea & 1007 & 7 & 3141 & 10423 & 14578 \\
\hline Central Anatolia & 48 & 125 & 4220 & 1240 & 5633 \\
\hline $\begin{array}{c}\text { Southeastern } \\
\text { Anatolia }\end{array}$ & 81 & 162 & 1969 & 32 & 2244 \\
\hline East Anatolian & 23 & 52 & 1459 & 197 & 1731
\end{tabular}

There is a delicate balance between our natural resources and the natural environment in which they are located, and this balance is called environmental balance. With excessive and unsuitable use of the natural environment, the ecological balance between our natural resources and our natural environment is disrupted, which causes a mitigation of environment, the habitat of all living beings and people. It is very difficult for water resources, land and the harmed ecosystem to be included in this ecological balance again. It is not only difficult to restore this deteriorated ecological balance but it is also very expensive [4]. Some of the pests and diseases that adversely affect the protecting of plants grown in greenhouses in Turkey are Tomato Leafminer (Tuta absoluta Meyrick), Tobacco whitefly (Bemisia tabaci Genn.), Leaf gallery flies (Liriomyza trifolii Burgess, L.bryoniae Kalt.),Aphids (Myzus persicae Sulz.), Red Spider Mite (Tetranychus.urticae Koch.), Thrips (Thrips tabaci Lind.), Noble Rot (Botrytis cinerea Pers.), Tomato Mildew (Phytophthora infestans Mont. De Bary), Kabakgillerde Mildiyö (Pseudoperonospora cubensis Berk. and Curt.) Soil- Borne Disease Fusarium spp., Verticillium spp, Rhizoctonia solani, Phytophthora spp., Pythium spp., Alternaria spp., Sclerotinia spp.)'. There are many harmful factors that directly and indirectly cause yield losses and harm product quality in agricultural production areas. For this reason, all factors should be considered together with their environment when combatting harmful factors. $[5,6]$. In addition to modern agricultural production techniques to increase the yield and quality of agricultural products in these production areas, one of the agricultural control methods applied to ensure quality production in order to protect agricultural products from the damage of diseases, harms and weeds is the use of plant protection products. Because of its effect in a short time and its simple use, the use of Plant Protection Products (PPP) is the most preferred one and therefore Chemical Control is carried out. It is known that there is a decrease of up to $60 \%$ in the quality and yield of products in places where chemical control is not carried out. For this reason, it is inevitable to use plant protection products in Turkey and in all other countries of the world, in order to control harmful organisms that cause crop loss [7]. However, the use of chemical pesticides to

2 | $\mathrm{P}$ a g e

www.iiste.org 
overcome the plant protection problems encountered in growing vegetables in greenhouses threatens human and environmental health. As a result of excessive use of chemical pesticides, the problem of pesticide residue occurs in the products and this creates an important problem in the export of products [8]. The emergence of breeds resistant to pests and diseases is a common problem in recent years [9, 10]. Due to such problems encountered in greenhouse vegetable cultivation threatening human and environmental health, new physical, biological and biotechnical methods are being used as an alternative to chemical control in the fight against pests and diseases in recent years $[11,12,13,14,15$, $16,17]$.

Various cases of environmental pollution occur during greenhouse cultivation activities. Serious environmental problems arise in water resources and in lands used for agricultural production and other activities. Pollution of many underground and aboveground water resources, soils becoming arid and salinization are among the problems encountered [18].

Along with the developing agricultural practices in the world, various chemicals (PPP) applied to the soil and plants pollute the soil and water resources and cause the disruption of the natural balance between living things in nature. These substances leak into lower layers of soil through rainfall and irrigation water, before being mixed with groundwater and polluting water and making it non-potable. The use of pesticides (PPP) as an important component of agricultural production is an important and fundamental issue that should be emphasized in terms of the risk of residue in agricultural products and negative impact on the environment.

With this research, plant protection practices and environmental awareness levels in the fight against plant protection problems encountered in vegetable cultivation in greenhouses located in the districts of Batman (Merkez, Beşiri, Kozluk and Sason), as well as solution suggestions have been discussed. At the same time, it became possible to determine all kinds of parameters that cause environmental pollution and environmental problems in all these activities. As a result, this study is expected to be beneficial for the nature and producers with appropriate solutions as well as realizing the principle of sustainable agricultural development for the prevention of agricultural pollution and protection of the environment.

It is important to make crop production permanent in agriculture in order to have regular and continuous use of seasonal labour in agricultural enterprises, and in this sense, to have a potential solution for unemployment in rural areas. In Batman, which has a significant potential in agricultural production in the region, the mild winter season constitutes a great advantage in terms of heating costs in greenhouse cultivation activities. In Batman province, greenhouse cultivation activities have increased significantly in terms of cultivated area and production amounts since 2009, with the support provided to the agricultural producers through the agricultural policies of the government. The greenhouse area in Batman, which was 61 decares in 2000, reached 317 decares in 2019. However, when compared to the total greenhouse area in the country $(690,000$ decares), it is revealed that the studies in this area should be intensified [20]. Located in the Southeastern Anatolia Region, the climate characteristics of Batman are generally within the context of Far Mediterranean Climate. The average annual precipitation is around $750-1000 \mathrm{~mm}$, winters are sometimes harsh and cold. In the research area, the greenhouse activity is generally cucumber and tomato cultivation and it is carried out in Zorköy, Yeniköy, Balpınar, Oymataş, İkiztepe villages of the central district, Doğankavak village of Beşiri district, Taşlidere and Arıkaya villages of Kozluk district and Köprübaşı and Umurlu villages of Sason district. In this study, the general condition of the greenhouse vegetable growing establishments operating in Batman region and the utilization conditions of the waste generated during and after the production season and the environmental effects of the waste were investigated. A map showing the research area is given in Figure 1. 

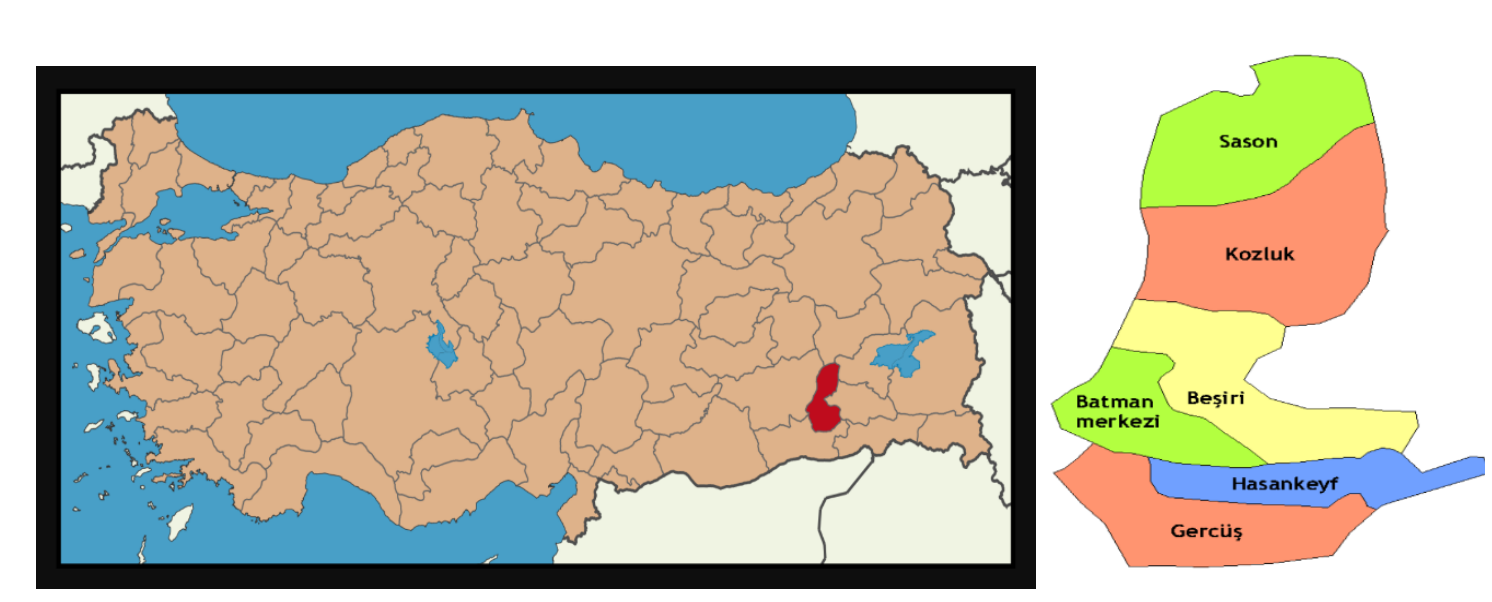

Figure 1.

This current study has been conducted in the greenhouse vegetable cultivation areas (cultivating tomato, pepper, cucumber and eggplant) in Batman Province, once in March and once in September 2021. For this purpose, questionnaire forms containing 30 questions on plant protection issues have been used to conduct face to face interviews with greenhouse vegetable growers with an area of $500 \mathrm{~m}^{2}$ and above in each district. The obtained answers have been given in numbers and rates.

Since it is not possible to conduct surveys with all the operating enterprises, the number of producers to be interviewed in the research was calculated by using "Simple Random Sampling Method" with the help of the below equation [21].

$$
n=\frac{N x S^{2} x t^{2}}{(N-1) x d^{2}+S^{2} x t^{2}}
$$

In the formula;

$\mathrm{n}$ : the sample volume,

$\mathrm{N}$ : Number of businesses in the population

$\mathrm{S}^{2}$ : Population variance

$\mathrm{d}$ is the deviation of a certain rate (5\%) from the mean,

$t$ is the table value of $t$ (1.65) corresponding to the $95 \%$ confidence limit. The conducted surveys have been processed through a Microsoft Windows 2016-based Excel program to assess the results, prepare a number of charts and graphics, make statistical calculations and determine average values. Data obtained from growers have been assessed after being presented in charts and graphics. The answers provided by the greenhouse vegetable growers to the survey questions have been assessed and the achieved findings have been calculated in percentages and given in charts.

\section{Results \& Discussion}

\subsection{Socio-Economic Characteristics of Greenhouse Growers}

An analysis of the demographic structure of the greenhouse growers participating in the survey conducted in Batman indicated that all growers are male, 51,6\% of them are primary school graduate, $35,5 \%$ are high school graduates and $12,9 \%$ are university graduate (Table 2). Education level is a significant indicator of the socio-economic levels of rural societies [22]. With regards to the education level of the greenhouse producers in Antalya province, a significant number, $68 \%$, of them are primary school, secondary school and high school graduates and a notable portion, $13 \%$ of them university graduates [23]. The number of higher education graduates has been found to be 5,38\% in Çukurova [24], 4\% in Aydın [25] and 2\% in Tokat [26]. This figure is 13\% in Antalya province. Producers with a

4 | P a g e

www.iiste.org 
high level of education is important as it ensures a higher level of awareness. The findings of this current study have indicated that level of education is particularly high among younger growers and younger growers make controlled production by making more frequent contacts with agricultural directorates. In addition, younger farmers seem to have a higher level of awareness which is important to overcome agricultural pollution.

The emphasis on environmental impacts was indirectly related to education. Because as the education level increases, the importance given to analysis increases, which prevents unnecessary and excessive use of fertilizers and environmental effects can be reduced. Based on the findings related to the participation of these growers in seminars, conventions or other similar training activities related to greenhouse cultivation, it has been observed that $3,2 \%$ of them never participated, $45,6 \%$ participated once, $40 \%$ participated between one and three times and $11,2 \%$ participated more than once.

Table 2. Demographic details of growers participating in the survey in Batman province

\begin{tabular}{l|l}
$\mathbf{( \% )}$ Trait & Ratio (\%) \\
\hline Gender & 100 \\
\hline Male & 0 \\
\hline Female & \\
\hline Education Level & \\
\hline Primary School & 51,6 \\
High School & 35,5 \\
\hline University & 12,9
\end{tabular}

\subsection{Opinions of Growers Regarding Timing of Pesticides}

Greenhouse growers have been asked about who they are consulting to diagnose the disease and pests in greenhouses and $41,9 \%$ of them pointed out to the technical personnel of provincial and district directorates of agriculture and forestry, $23,8 \%$ vendors and 34,3\% replied that they consult their neighbours or their own knowledge (Table 3). These figures indicate that the greenhouse growers in Batman have a sufficient level of knowledge regarding diseases and pests. Another study conducted in Antalya has analysed the level of knowledge of greenhouse producers regarding disease, pest and weed, and it has indicated that 58\% have detailed knowledge while $31 \%$ are aware of them but do not have enough knowledge. Their knowledge on the contamination and spreading of these was sufficient [23].

Table 3. The level of knowledge of greenhouse producers with regards to the diagnosis of diseases and pests in greenhouse areas

\begin{tabular}{l|l} 
Who is diagnosing the diseases & Ratio (\%) \\
and pests in greenhouse areas? & \\
\hline Vendor & 23,8 \\
\hline $\begin{array}{l}\text { District Directorate of Agriculture } \\
\text { and Forestry }\end{array}$ & 41,9 \\
\hline I do myself or ask my neighbour & 34,3
\end{tabular}

Greenhouse producers have been asked about the timing of pesticides against disease and pests in greenhouse. According to the answers, 45,2\% of them apply pesticides at the first appearance of disease and pests, $45,2 \%$ of them apply based on the recommendations given by the provincial/district directorate of agriculture and forestry, 3,1\% of them consult their vendor and $6,5 \%$ of them apply pesticide before the appearance of any disease and pest (Table 4). An effective chemical combat against

5 | $\mathrm{P}$ a g e

www.iiste.org 
disease and pests can only be ensured through a well-timed application of pesticides. A good timing will help to achieve the greatest impact and make it economic. The answers provided by producers are noteworthy. Because a portion of 39\% have replied that they apply pesticides whenever they observe disease and pests or depending on their intensity. In this sense, it is possible to say that producers are familiar with disease and pests and they possess the necessary technical knowledge, even if it is not at a sufficient level. The general consensus is that the correct time of applying pesticides is the one that takes the plant phenology into consideration. However, when the disease and pest biology is taken into consideration to decide on the timing, it is not possible for the producers to correctly decide on the timing of applying pesticides, because this requires technical knowledge and experience and this can only be achieved through training given by relevant technical personnel. Other studies had similar conclusions to this current study. According to one such study conducted by [12], 42,15\% of the growers base their timing decision on their own experiences, 9,80\% consult people around them, $34,31 \%$ consult agricultural agencies while $13.72 \%$ consult their vendor. Another study conducted by [24] in Çukurova area reported that $38,64 \%$ of growers base their decision on dosage and timing on their own experience and on the recommendation provided by vendor, $35 \%$ base their decision on their own experiences, $19,09 \%$ base their decision on the recommendation provided by vendor, $5,45 \%$ base their decision on the recommendation provided by technical agencies while $1,82 \%$ base their decision on label. [8] reported that $40,18 \%$ of producers base their decision on dosage and timing on the recommendations of vendors, $29,92 \%$ base their decision on their own experience and $16,23 \%$ base their decision on pesticide label. [27] conducted a study in Konya and reported that 44,20\% of the producers base their decisions on timing on their own experience, $24,20 \%$ on the recommendations provided by vendors, $20 \%$ consult other producers while $11.60 \%$ consult agricultural agencies. A study conducted by [26] in Tokat province reported that $58,74 \%$ of the producers base their decisions on pesticide timing on technical personnel, 29,14\% decide it themselves, $6,20 \%$ observe the instructions of vendors while $5,81 \%$ of them consult other farmers. [28] reported that $35 \%$ of apple producers apply pesticides as soon as they observe disease and pests while $22 \%$ base their decision on the early warning system. In contrast to the findings of this study, [29] reported that $43,2 \%$ of apple producers in Karaman province apply pesticide before observing any pests while 56,8\% apply pesticides after observing pests; [30] reported that $56 \%$ of vineyard producers in Manisa apply pesticide after observing disease and pest while 34\% apply pesticide before they observe any disease and pest; and [31] reported that when the producers in Antalya agricultural production areas decide on the timing of applying pesticides, $89,4 \%$ base their decision on the propagation status of disease while $10.6 \%$ consider the cost first.

Table 4. The level of knowledge of greenhouse producers with regards to timing the pesticide application against disease and pests in greenhouses

\begin{tabular}{|c|c|}
\hline $\begin{array}{l}\text { How do you decide on the timing of } \\
\text { applying pesticide against disease and } \\
\text { pests in greenhouses? }\end{array}$ & Ratio (\%) \\
\hline Vendor & 3,1 \\
\hline $\begin{array}{l}\text { District Directorate of Agriculture and } \\
\text { Forestry }\end{array}$ & 45,2 \\
\hline After first observing disease and pests & 45,2 \\
\hline Before observing any disease and pests & 6,5 \\
\hline
\end{tabular}

\subsection{The knowledge, attitude and behaviours of producers with regards to plant protection products}

With regards to pesticide advise and selection, $45,2 \%$ of greenhouse producers in Batman consult the provincial/district directorate of agriculture and forestry, 19,4\% consult vendors while 35,4\% base their pesticide selection on their own experiences and no suggestions provided by their neighbors (Table 5). Similar to our findings, [32] have reported that $65 \%$ of vineyard producers in Manisa base their 6 | P a g e www.iiste.org 
pesticide selection on recommendation from provincial/District Directorate of Agriculture, $16 \%$ use their own experience, $11 \%$ consult a vendor and $8 \%$ consult their neighbors; when deciding on which pesticide to use, $54 \%$ of apple producers seek advice from vendors, $10 \%$ seek advice from an agricultural engineer [33]; 43,08\% of the fruit producers in Gümüşhane base their pesticide selection on advise provided by technical personnel, $3,08 \%$ base their decision on advise provided by vendor [34]; $66,9 \%$ of agricultural producers in Antalya stated that they consult vendors when selecting pesticides [31]. In contrast to the findings of this study, [35] reported that $49,7 \%$ of citrus produces in Antalya base their decisions on their own experiences, $42,8 \%$ consult their vendor, $4 \%$ consult the Provincial/District Directorate of Agriculture and 3,4\% consult their neighbors. According to [36], 33\% of farmers consult vendors, $22 \%$ consult provincial and district directorates of agriculture and forestry, $17 \%$ rely on their own experiences, $10 \%$ consult elder members of their families, $9 \%$ consult agricultural engineers and 3\% consult agricultural chambers to receive technical knowledge pest control while $6 \%$ do not receive any "technical assistance.

Table 5. Source of pesticide recommendation

\begin{tabular}{l|l}
\hline $\begin{array}{l}\text { Who is advising you on pesticides } \\
\text { (fungicide, herbicide and insecticide)? }\end{array}$ & Ratio (\%) \\
\hline Vendor & 19,4 \\
\hline $\begin{array}{l}\text { District Directorate of Agriculture and } \\
\text { Forestry }\end{array}$ & 45,2 \\
\hline My own experience and my neighbour & 35,4 \\
\hline
\end{tabular}

With regards to selecting (or purchasing) pesticides (fungicide, herbicide and insecticide) to be used against disease and pests, $32,5 \%$ of greenhouse producers select one that has been previously used, $21,5 \%$ look or the recommended active substance, $29,6 \%$ look for the brand and $16,4 \%$ look for cheaper ones (Table 6). [27] reported that $62,8 \%$ of producers base their pesticide selection on the intensity of disease, $21,5 \%$ base it on disinfestation costs and $15,7 \%$ base their decision on the price; [28] report that $78 \%$ of apple producers base their pesticide selection on the intensity of disease and pest, $11 \%$ on price and $6 \%$ on disinfestation costs; and [37] reported that $87,5 \%$ of the tomato producers taking part in a survey conducted in Tokat Kazova base their pesticide selection on price while $1,39 \%$ base it on the impact on environment

Table 6. Decisive factors when purchasing pesticide (Fungicide, herbicide and insecticide)

\begin{tabular}{l|l}
$\begin{array}{l}\text { What do you look for when } \\
\text { purchasing pesticide (fungicide, } \\
\text { herbicide and insecticide)? }\end{array}$ & \\
\hline Previous use & 32,5 \\
\hline Recommended active substance & 21,5 \\
\hline Brand & 29,6 \\
\hline Price & 16,4
\end{tabular}

Batman is a province with a significant potential of greenhouse production and $73,5 \%$ of the local producers prefer not to use the same pesticide for the same disease and pest while $26,5 \%$ keep using the same pesticide (Table 7). A study conducted by [38] reported that $93,1 \%$ of producers prefer not using the same pesticide for the same disease and pest all the time while $6,9 \%$ keep using the same pesticide. 
Table 7. Attitude of producers towards using the same pesticide for the same disease and pest

\begin{tabular}{l|l}
$\begin{array}{l}\text { Are you constantly using the } \\
\text { same pesticide for the same } \\
\text { disease and pest? }\end{array}$ & $\begin{array}{l}\text { Ratio } \\
(\%)\end{array}$ \\
\hline Yes & 26,5 \\
\hline No & 73,5
\end{tabular}

Producers have been asked about the resources they avail to determine the pesticide dosage when employing chemical control methods in greenhouses. According to the answers, $19,4 \%$ consult their vendor, 25,8\% consult the Provincial/District Directorate of Agriculture, 45,2\% refer to printed brochures, 6,5\% rely on their own experiences and 3,1\% consult their neighbour (Table 8). [35] reported that in terms of determining dosage, $41,71 \%$ of citrus producers rely on the pesticide's product label, $27,81 \%$ rely on their own experience; [39] reported that $8,3 \%$ of the producers in Konya rely on the product label to have the correct pesticide dosage, $26,6 \%$ rely on their own experience, $11,6 \%$ consult their neighbour, $33,3 \%$ rely on the instructions of vendors, $10,8 \%$ consult the Provincia1/District Directorate of Agriculture, 3,3\% consult agricultural chambers and 5,8\% consult an agricultural engineer; [40] reported that $33,33 \%$ of the producers consult a vendor and an agricultural engineer for the correct dosage; [37] reported that producers consult the pesticide-fertiliser vendors $(90,28 \%)$, pesticide prospectus $(59,72 \%)$, their own experiences $(40,28 \%)$, technical staff from the Provincial/District Directorate of Food, Agriculture and Livestock $(1,39 \%)$ and the intensity of the disease $(1,39 \%)$ to figure out the correct pesticide dosage.

Table 8. Producers' level of knowledge regarding the dosage of pesticides to be used

\begin{tabular}{l|l}
$\begin{array}{l}\text { How do you determine the pesticide (Fungicide, } \\
\text { herbicide and insecticide) dosage? }\end{array}$ & Ratio (\%) \\
\hline Vendor & 19.4 \\
\hline District Directorate of Agriculture and Forestry & 25,8 \\
\hline Printed brochures & 45.2 \\
\hline Own experience & 6.5 \\
\hline Neighbour & 3.1
\end{tabular}

It has been observed that $74,2 \%$ of greenhouse producers apply the exact recommended dosage, $12,9 \%$ exceed the recommended dosage, 9,7\% sometimes exceed the recommended dosage while $3,2 \%$ generally exceed the recommended dosage. (Table 9). The fact that a great majority of the producers are applying the exact recommended dosage makes it possible to succeed in chemical pest control. Similar to the findings of this study, [32] reported that $72 \%$ of vineyard producers apply the recommended dosage, $26 \%$ exceed the recommended dosage and $2 \%$ apply an estimated dosage; [40] reported that $88 \%$ of the producers in Konya apply the recommended dosage, $8 \%$ exceed the dosage and $4 \%$ apply a lower dosage; [38] reported that 50,7\% of the producers apply the recommended dosage while $50,3 \%$ exceed the recommended dosage. In contrast to the findings of this study, [25] reported that $64,47 \%$ of the producers in Aydın exceed the recommended dosage. 
Table 9. Knowledge related to the recommended application dosage of pesticide

\begin{tabular}{l|l}
$\begin{array}{l}\text { Is the pesticide (Fungicide, herbicide and } \\
\text { insecticide) applied in accordance to the } \\
\text { recommended dosage? }\end{array}$ & \\
\hline I observe the recommended dosage & 74,2 \\
\hline I sometimes exceed the recommended dosage & 12,9 \\
\hline I sometimes recede the recommended dosage & 9,7 \\
\hline I generally recede the recommended dosage & 3,2
\end{tabular}

With regards to the producers' level of knowledge about pesticide residue, it has been observed that $43,3 \%$ of the greenhouse producers in Batman stated that pesticides leave residue on the products, $13,3 \%$ stated no residue is left behind, $26,7 \%$ stated that pesticide residue can be washed-off and $16,7 \%$ stated they have no knowledge of any pesticide residue (Table 10). In other similar studies, it has been reported that $70,4 \%$ of the producers in Antalya observed pesticide residue on products, $10,4 \%$ washedoff pesticide residues, $19,2 \%$ had no idea, $34,3 \%$ of the producers stated that pesticides can leave residue on product, $23,8 \%$ stated that all chemicals leave some residue, $18,1 \%$ stated that no residue will be left as long as the recommended dosage is applied, 13,4\% stated that residue can be washed and $10,4 \%$ stated that pesticides do not leave any residue behind; $28,3 \%$ of the producers in Konya stated that pesticides can leave residue on the products, $18,3 \%$ stated there will be no residues left, 7,5\% had no information and $45,8 \%$ stated that pesticides will be washed-off by rainwater; $44,44 \%$ of the tomato producers in Tokat Kazova stated that agricultural chemicals leave residue on the product, 15,63\% stated that residue is only observed when the recommended dosage is exceeded, $15,63 \%$ stated that all chemicals leave some residue and $9,38 \%$ stated that no residue will be left when the recommended dosage is applied [35, 37, 39]. In contrast to the findings of this study, [41] concluded that $80 \%$ of the producers believe pesticides leave no residue on products while $20 \%$ believe they leave residue behind; According to [31], $23.3 \%$ of the producers stated that pesticide residues can be washed-off, $24.9 \%$ stated that there will be residues left, $34.1 \%$ stated that only certain pesticides can leave residues while $17.7 \%$ stated that they had no knowledge of any pesticide residues.

Table 10. The level of knowledge of producers regarding pesticide residues

\begin{tabular}{l|l}
$\begin{array}{l}\text { Do you know that pesticides leave residue on } \\
\text { products? }\end{array}$ & Ratio (\%) \\
\hline They do leave residue & 43,3 \\
\hline No residue is left & 13,3 \\
\hline Residue can be washed-off & 26,7 \\
\hline Have no idea & 16,7
\end{tabular}

$75,6 \%$ of the producers applying pesticides in greenhouse observe the waiting time for pesticides while $24,4 \%$ do not observe the waiting times (Table 11). Having a great majority of the producers to observe the waiting times is a positive thing. [28] reported that $71 \%$ of the apple producers observe the waiting time between disinfestation and harvesting while $29 \%$ do not; [42] has reported that $76,6 \%$ of the producers do not observe the waiting time after disinfestation while $23,4 \%$ is observing; [29] reported that $43,2 \%$ of the producers observe the waiting time, $32,8 \%$ do not observe it despite being aware of it and $24 \%$ never heard of any waiting time. [37] reported that $91,67 \%$ of the producers are not aware of the waiting time to be observed between the final disinfestation and harvest, $6,94 \%$ are aware of it but do not observe it while $1,39 \%$ are aware of it and observe it.

9 | $\mathrm{P}$ a g e

www.iiste.org 
Table 11. Level of knowledge of producers regarding the duration between disinfestation and harvest

\begin{tabular}{l|l}
$\begin{array}{l}\text { Do you observe the waiting } \\
\text { time in pesticides? }\end{array}$ & $\begin{array}{l}\text { Ratio } \\
(\%)\end{array}$ \\
\hline Yes & 75,6 \\
\hline No & 24,4
\end{tabular}

An analysis of the producers' knowledge regarding the precautions to be taken during disinfestation has revealed that $61,3 \%$ of the producers use protective garment and mask during disinfestation in greenhouse while $38,7 \%$ never use any protection. It has been observed that almost half of vineyard producers do not take sufficient protective measures during disinfestation (Table 12). Similar to the findings of this study, [35] reported that $68,8 \%$ of producers use protective garment and mask during disinfestation while $31,2 \%$ do not; [43] reported that $61 \%$ of producers wear a mask as a precaution; [44] reported that about $70 \%$ of producers do not wear a disinfestation mask and $90 \%$ do not wear an overall/disinfestation clothing.

[45] reported that $76 \%$ of producers take protective measures during disinfestation while $24 \%$ do not take any protective measures. In contrast to the findings of this study, [32] reported that 57,82\% of producers use protective garment and mask during disinfestation while 42,18\% never use any; [31] reported that $42.1 \%$ of producers use protective equipment during disinfestation while $31.7 \%$ do not use any as they don't consider such equipment to be necessary.

Table 12. Level of knowledge of producers regarding the measures to be taken during disinfestation

\begin{tabular}{l|l}
$\begin{array}{l}\text { How do you protect your health during } \\
\text { disinfestation? }\end{array}$ & $\begin{array}{l}\text { Ratio } \\
(\%)\end{array}$ \\
\hline $\begin{array}{l}\text { Do you use protective garment, mask, } \\
\text { goggles and gloves during disinfestation? }\end{array}$ & \\
\hline I always do & 61,3 \\
\hline I never did & 38,7 \\
\hline
\end{tabular}

Producers have been asked how they are disposing of the empty pesticide boxes following disinfestation. $3 \%$ of the participants replied that they wash the box for re-use, $3,7 \%$ replied that they bury it underground, $42 \%$ replied they throw them away along with domestic waste, $41,6 \%$ replied they burn it and 13\% replied they throw away randomly (Table 13). Studies conducted in relation to this subject have indicated that producers have different types of reactions when it comes to handling empty pesticide boxes. According to [35], 7,45\% of producers burn the empty pesticide boxes, $21,81 \%$ throw them in bins, $14,36 \%$ bury them and 7,45\% throw them away randomly; [32] reported that $60,54 \%$ of producers throw away the empty pesticide boxes randomly, 4,98\% re-use them, $19 \%$ bury them and $15,48 \%$ burn them; [46] reported that $35,6 \%$ of producers bury the empty pesticide boxes, $34,6 \%$ throw them in the fields and $29,8 \%$ throw them in bins; [43] reported that $61,1 \%$ of producers in Çukurova store the empty pesticide boxes in a place before burning them all; [30] reported that $65,3 \%$ of vineyard producers burn the empty pesticide boxes, $24 \%$ throw them away randomly and $10,7 \&$ bury them; [37] reported that $59,72 \%$ of producers burn the empty pesticide packages, $29,17 \%$ bury them, 5,56\% throw them away along with domestic waste and 5,56\% throw them away randomly; [31] reported that $8.5 \%$ of producers leave empty pesticide boxes in environment, 55\% burn them, $10 \%$ bury them, $26.2 \%$ throw away along with domestic waste and $0.3 \%$ re-use. 
Table 13. Producer's level of knowledge on handling empty pesticide boxes

\begin{tabular}{l|l}
$\begin{array}{l}\text { What do you do with the empty } \\
\text { pesticide (fungicide, herbicide and } \\
\text { insecticide) boxes? }\end{array}$ & $\begin{array}{l}\text { Ratio } \\
(\%)\end{array}$ \\
\hline Wash and re-use & 3 \\
\hline Bury in ground & 3,7 \\
\hline Domestic waste & 38,7 \\
\hline Burn & 41,6 \\
\hline Leave in environment & 13
\end{tabular}

In Batman, 93,5\% of greenhouse producers stated that they clean the disinfestation tool after disinfestation, $2 \%$ stated that they only clean it sometimes and 4,5\% stated that they never clean it (Table 14). 85,42\% of the vineyard producers in Manisa stated that they wash the disinfestation tool after disinfestation while $14,58 \%$ never wash it; $69,2 \%$ of the producers in Iğdır stated that they wash the disinfestation tool, $27,9 \%$ stated that they sometimes wash it while $2,9 \%$ stated that they never wash it; $[32,46]$.

Table 14. Producers' level of knowledge regarding cleaning of the disinfestation tool after disinfestation

\begin{tabular}{ll|l}
$\begin{array}{l}\text { Are you cleaning } \\
\text { disinfestation } \\
\text { disinfestation? }\end{array}$ & $\begin{array}{r}\text { the } \\
\text { after }\end{array}$ & $\begin{array}{l}\text { Ratio } \\
(\%)\end{array}$ \\
\hline $\begin{array}{l}\text { I do } \\
\text { I sometimes do }\end{array}$ & 93,5 \\
\hline I do not & 2 \\
\hline
\end{tabular}

The producers' level of knowledge regarding mixed-use of pesticides have been analyzed and it has been concluded that $55,5 \%$ of greenhouse producers use a mixture of pesticides, $16,5 \%$ sometimes mixed them and 28\% never mix them (Table 15). Similar to the findings of this study, [28] reported that $83 \%$ of apple producers make a mixture of pesticides, $17 \%$ never mix the pesticides; [41] reported that $56 \%$ of producers mix pesticides, $24 \%$ never mix the pesticides and $20 \%$ sometimes mix the pesticides; [38] reported that $56,1 \%$ of producers make a mixture of pesticides, $43,9 \%$ never mix them.

Table 15. Producers' level of knowledge regarding mixed-use of pesticides

\begin{tabular}{l|l}
$\begin{array}{l}\text { Are you mixing pesticides before } \\
\text { usage? }\end{array}$ & $\begin{array}{l}\text { Ratio } \\
(\mathbf{\%})\end{array}$ \\
\hline I mix them & 55,5 \\
I sometimes mix them & 16,5 \\
\hline I never mix them & 28
\end{tabular}

With regards to the producers' level of knowledge about the methods of controlling diseases, pests and weeds, it has been observed that $30,5 \%$ of greenhouse producers employ chemical control methods, $37,5 \%$ employ cultural measures, $14,1 \%$ employ mechanical control methods, $11,5 \%$ employ 
biotechnical control methods and 5,4\% employ physical control methods (Table 16). Similar to the findings of this study, it has been reported that further to chemical control methods, $88,4 \%$ of producers prefer cultural control methods, $10,5 \%$ prefer mechanical control methods and $1,1 \%$ prefer physical control methods [38]. In contrast to these findings and further to chemical control methods, $43,58 \%$ of the producers in Tokat prefer cultural control methods, 33,33\% prefer mechanical control methods and $23,07 \%$ prefer physical control methods [26]. On the other hand, it has been reported that $83,3 \%$ of the producers in Antalya prefer chemical control methods against diseases, pests and weeds [31]. Another study has concluded that in terms of environmental health and sustaining natural balance, chemical disinfestation must be avoided in pest control and more importance should be given to cultural control methods [47].

Table 16. Producers' level of knowledge regarding the methods of controlling diseases, pests and weeds

\begin{tabular}{l|l}
$\begin{array}{l}\text { Methods of controlling } \\
\text { diseases, pests and weeds }\end{array}$ & $\begin{array}{l}\text { Ratio } \\
(\mathbf{\%})\end{array}$ \\
\hline Chemical control & 30,5 \\
\hline Cultural measures & 37,5 \\
\hline Mechanic control & 14,1 \\
\hline Biotechnical control & 11,5 \\
\hline Physical control & 5,4
\end{tabular}

$96,5 \%$ of the greenhouse producers stated that they are not aware of the term biopesticide while $3,5 \%$ have already heard of it (Table 17). In line with the findings of this study, [38] concluded that 97,4\% of producers are not aware of the term biopesticide while $2,6 \%$ are aware of the term biopesticide. In contrast to these findings, $52 \%$ of the producers in GAP region have already heard of the term biopesticide while $48 \%$ never heard of it [45]. In terms of environmental health and sustaining natural balance, chemical disinfestation must be avoided in pest control and more importance should be given to biotechnic methods and cultural control methods [47]. Considering that a great majority of greenhouse producers in Batman base their pesticide selection on advice provided by Provincial/District Directorates of Agriculture and vendors, agricultural agencies and vendors have important roles to play with regards to biopesticide and biologic control.

Table 17. Level of knowledge regarding the term biopesticide

\begin{tabular}{l|l} 
Do you know what biopesticide is? & Ratio (\%) \\
\hline I do Not know & 96,5 \\
\hline I do know & 3,5
\end{tabular}

\section{Conclusion}

The findings of this study, held in Batman province where an important greenhouse potential exists, indicate that the local producers have a high level of education and several of them have social security and non-agricultural income. It has been found that the local producers mostly prefer chemical control methods against existing disease and pests to ensure productive and high-quality yield in greenhouse production areas. Random and wrongful use of pesticide could be harmful as such practices would damage both human and environmental health and can lead to a resistance in disease and pests against pesticides over time. Therefore, a more effective, economic and eco-friendly control can be made by using suitable pesticides and this will help avoiding any undesired side effects. In order to achieve this by preventing insensible use of pesticides, it is very important that agricultural agencies and

12 | P a g e

www.iiste.org 
universities educate farmers on the use of pesticide-use and direct them towards other alternative methods. In conclusion, integrated control must play a greater role against the main disease and pests in greenhouse vegetable production and if chemical control is unavoidable, pesticides that are relatively safer for human and environmental health must be preferred. It has been observed that the agriculturerelated publications in the region need to increase the environmental awareness of the producers. It is important that producers are encouraged to learn through various education and certificate activities organized by agricultural publication institutions. The used packages of chemical fertilizers and pesticides can be purchased by the state, even for symbolic prices, from the farmers and this can reduce the negative impact on the environment. It is known that the Ministry of Environment's decision to introduce a price for the plastic shopping bags, previously given away for free, has significantly reduced their use. Furthermore, if the relevant methods are preferred to reduce the use of chemical pesticides, pesticide residues on products will be avoided and pests will not be able to develop resistance against pesticides. This will also help to reduce costs.

\section{References}

[1].Anonymous, 2019. Turkey Statistical Institute (TUIK), Turkey Belongs to the 2018 Protected Areas Quantity Data https://biruni.tuik.gov.tr/ (Accessed: 02/01/2019).

[2].Saltuk, B. 2018. Current Situation in Mediterranean Greenhouses and a Structural Analysis Example (Mersin Province) Fresenius Environmental Bulletin Volume 27 No. 12B / 2018 pages 9954-9961 (SCI-Exp)

[3].Saltuk, B. 2019. Determination of Greenhouse Potential in Siirt Province and Districts by Using GIS and Recommendations to Producers. European Journal of Science and Technology No. 15, pp. 343-350, March 2019.

[4].Güler, Ç. \& Çobanoğlu, Z. 1997. Soil Pollution, T.C. Ministry of Health, Environmental Health Basic Resource Series, 40, 48, Ankara.

[5].Kaplan, M. (2019a). Insect species that are harmful in olive groves in Mardin province, their distribution and density. Journal of Iğdır University Institute of Science, 9 (4): 1901-1907, ISSN: 2146-0574.

[6].Kaplan, M. (2019b). It is the time to see harmful and beneficial insect species and some important pest species found in some cherry orchards in Diyarbakir. European Journal of Science and Technology Issue 17, p. 283-289, December 2019. ISSN: 2148-2683.

[7].Turabi, M.S. 2007. Licensing of Plant Protection Products. Agricultural Medicines Congress and Exhibition, TMMOB Zir. Chamber of Engineering and TMMOB Chamber of Chemical Engineering, Proceedings, p: 50-61, 25-26 October 2007).

[8].Zeren, O., ve Kumbur, H., 1998 Research on Agricultural Pharmaceutical Marketing, Usage Technique and Effectiveness in Içel Province. Turk- Koop Ekin 2: 5, p: 62-68

[9].Metcalf, R. L. 1975. Insecticides in pest management. In: Introduction to Insect Pest Management (R.L. Metcalf \& W.H. Luckmann (eds.), Wiley-Interscience Pub., New York, pp. $235-273$

[10]. Staub, T. 1991. Fungicide resistance: practical experience with anti-resistance strategies and the role of integrated use. Annual Review of Phytopathology, 29: 421-442.

[11]. Öncüer, C., Z. Yoldaş, N. Madanlar ve A. Gül, 1994. Biological control practices against pests in vegetable greenhouses in İzmir. Turkey III. Biological Control Congress Proceedings (25-28 January 1994, İzmir), Ege University Press, Bornova-İzmir, p. 395-407. 
[12]. Yücel, A., Çıkman, E., ve Yücel, M., 1995. The Perspective of the Agricultural Struggle of the Farmer in the Harran Plain before the Southeastern Anatolia Region (GAP) was put into practice. GAP Region Plant Protection Problems and Solution Proposals Symposium, 27-29 April 1995, Şanlıurfa

[13]. Aysan, Y., N. Sarı, A. Erkılıç, Ö. Çınar ve Abak K., 1995. Effects of soil solarization on disease development and yield with a variety resistant to tomato bacterial black spot disease. VII. Phytopathology Congress of Turkey (26-29 September 1995 Adana), Gene Matt. Ltd. Ankara, p. 418-422

[14]. Yaşarakıncı, N., P. Hıncal, S. Öz, N. Filiz, İ. Çınarlı, N. Ertekin, G. Demir, Ü. Fidan, P. Taşdelen, A. Tokaç ve M. Saltabaş, 1996. Integrated control practices in greenhouse tomato cultivation in the Aegean region. Turkey III. Entomology Congress Proceedings (24-28 September 1996, Ankara), Ankara Univ. Press, Ankara, p. 98-108.

[15]. Yoldaş, Z., N. Madanlar ve A. Gül, 1996. Research on biological warfare possibilities against eggplant pests in greenhouses in Izmir. Turkey III. Entomology Congress Proceedings (24-28 September 1996, Ankara), Ankara University Press, Ankara, p. 206-213

[16]. Yücel, S., H. Pala, S. Çalı ve A. Erkılıç, 1999. The effect of solarization and Trichderma harzianum applications against some soil-borne disease factors in greenhouses. Turkey IV. Biological Control Congress Proceedings (26-29 January 1999, Adana), Çukurova Univ. Publishing House, Adana, p. 169-176.

[17]. Yabaş, C., A. Ulubilir, and A. Yiğit, 2000. Effect of Mass Trapping by Yellow Sticky Traps in Controlling of Leafminer, Liriomyza spp. (Diptera: Agromyzidae) Injurious on Vegetables in Greenhouses in Icel. Integrated Control in Protected Crops, Mediterranean Climate, IOBC WPRS Bulletin, 23 (1): 145-149

[18]. Atılgan A., Coşkan A., Saltuk B., Erkan C. M. 2007. Chemical and Organic Fertilizer Usage Levels in Greenhouses in Antalya Region and Possible Environmental Effects.

[19]. Anonymous, 2020a. Greenhouse cultivation in Batman province. http://www.batman.gov.tr. (Access date: 28.12.2020)

[20]. Anonymous 2020b. Batman province general information. File: Latrans-Turkey location Batman.svg - Wikipedia (wikipedia.org) (Accessed date: 28.12.2020)

[21]. Çiçek, A. ve Erkan, O., (1996). Research and Sampling Methods in Agricultural Eco-nomics. GOP Univ. Ziraat Faculty Publications No: 12, Lecture Notes Series No: 6, Tokat.

[22]. Özçatalbaş, O. ve Gürgen, Y., 1998. Agricultural Extension and Communication. Baki BookPublishing House, ISBN: 975-72024-02-3, Adana.

[23]. Yanar, D., , Yanar, Y., Erdal, H., Erdal, G,, Poyraz, E., 2018. Plant Protection Problems Encountered in Greenhouse Growing in Antalya Province and Producer Awareness Level Gaziosmanpaşa Scientific Research Journal (GBAD), Vol / Volume: 7 Issue / Number: 3, Page / Pages: 38-48.

[24]. Üremiş, İ., Karaat, Ş., Gönen, O., Canıhoş, E., Kütük, H., Ekmekçi, U., Çetin, V., Aytaş, M., ve Kadıoğlu, İ., 1996. General Evaluation of Pesticide Use in Çukurova Region. II. National Pesticides Symposium 18-20 November 1996, Ankara, p: 73-79.

[25]. Boz Ö, Erol T, Benlioğlu S, Öncüer C. 1998. Socio-economic evaluation of agricultural control practices in Aydın. Turkey Journal of Entomology, 22 (2): 123-136. 
[26]. Kadığlu İ. 2003. A research on agricultural control activities of producers in Tokat province. Gaziosmanpaşa University Faculty of Agriculture Journal, 20 (1): 7-15.

[27]. İnan H, Boyraz, 2002. General evaluation of Konya farmer's use of pesticides. Selcuk University Faculty of Agriculture Journal, 16 (30): 88-101.

[28]. Boyraz N, Kaymak S, Yiğit F. 2005. General evaluation of chemical control practices of apple producers in Eğirdir district. Selcuk University Faculty of Agriculture Journal, 19 (36): 37-51.

[29]. Karaçayır HF. 2010. Extension approaches in the use of pesticides in agricultural enterprises producing apple: the case of the province of Karaman. Master Thesis, Selcuk University Institute of Science, Department of Agricultural Economics, 158 p, Konya.

[30]. Karataş E, Alaoğlu Ö. 2011. Plant protection practices of producers in the province of Manisa. Ege University Faculty of Agriculture Journal, 48 (3): 183-189.

[31]. Akar Ö., Tiryaki O. 2018. Information on Producers' Use of Pesticides in Antalya Province Investigation of Level and Sensitivity. Süleyman Demirel University Faculty of Agriculture Journal 13 (1): 60-70,

[32]. Tücer A, Polat İ, Küçüker M, Özercan A. 2004. Determining the problems in pesticide applications in Manisa Saruhanlı vineyard areas Anadolu, J of AARI, 14 (1): 128-141.

[33]. Ay R, Yalçın Ş, Sökeli E, Karaca İ. 2006. Investigation of stone fruit producer profile in Korkuteli district of Antalya province in terms of plant protection applications. SDU Journal of Science Institute, 10 (1): 52-55.

[34]. Kalkışım Ö, Onaran A, Azeri FN, Turan A. 2011. A research on the general situation of fruit growing and farmer practices in the province of Gümüşhane and its districts. Gümüşhane University Journal of the Institute of Science, 1 (2): 123-134.

[35]. Özkan B, Vuruş Akçaöz H, Karadeniz CF. 2003. Producer attitudes and behaviors towards the use of pesticides in citrus production in Antalya. Anadolu, J. of AARI, 13 (2): 103-116.

[36]. Dilmen H., Pala, F., ve Özer Dilmen, M., 2019. Pistachio (Pistacia vera L.) Determination of Agricultural Producers Struggle Knowledge levels: Turkey, Siirt Example.- Turkish Journal of Agricultural Research 7(1): 1-8.

[37]. Gözener B, Sayılı M, Çağlar A. 2017. Drug use in tomato cultivation in Kazova region of Tokat province. Turkish Journal of Agriculture-Food Science and Technology, 5 (5): 451-458

[38]. Erdoğan O, Gökdoğan O. 2017. Plant protection practices of potato producers in Nevşehir province. Western Mediterranean Agricultural Research Institute Derim Journal, 34 (1): 51-60

[39]. Kalipci, Erkan \& Ozdemir, Celalettin \& Oztas, Haydar. (2011) Investigation of Environmental Awareness and Education and Information Levels of Farmers Related with Pesticide Usage. TÜBAV Science Journal. 4. 179-187.

[40]. Gedikli O. 2012. Evaluation of the problems faced by the producers of Samsun spruce, and Terme districts in terms of plant protection and the factors affecting the use of pesticides. Master Thesis, Atatürk University Institute of Science, Department of Plant Protection, 92 p, Erzurum.

[41]. Peker AE. 2012. Environmental sensitivity analysis for the use of pesticides in tomato production in Konya province. Journal of Iğdır University Institute of Science, 2 (1): 47-54 
[42]. Emeli M. 2006. A research on the application problems of plant protection methods in Seyhan and Yuregir basin. Master Thesis, Cukurova University Institute of Science, Department of Plant Protection, 123 p, Adana.

[43]. Akbaba BZ. 2010. Evaluation of citrus cultivation and insecticide use in Adana province. Master Thesis, Cukurova University Institute of Science, Department of Plant Protection, 89 p, Adana.

[44]. Şimşek, Z., Demir C., Kara B., Akpirinç, S. ve Erçetin, G. 2012. Safe Pesticide Use Behavior of Seasonal Agricultural Workers. 1. Agricultural Health and Safety Symposium, 6-7 April 2012, Şanlıurfa, 230-232.

[45]. Bayhan E, Sağır A, Uygur FN, Bayhan SÖ, Eren S, Bayram Y. 2015. Determination of plant protection problems in cotton fields in the GAP Region. Turkey Entomology Bulletin, 5 (3): 135-146.

[46]. Ertürk YE, Bulak Y, Uludağ A. 2012. Environmental sensitivity of agricultural enterprises in Iğdır province in agricultural control practices. Journal of History, Culture and Art Studies, 1 (4): 393-401.

[47]. Kaplan, M. (2019c). Determining of Some Struggle Opportuities for Cicada (Lyristes Plebejus Scopoli) (Hemiptera: Cicadidae) and Weeds Which is Harmful in Apricot Orchards in Turkey. Fresenius Environmental Bulletin, Volume 28 - No. 10/2019 pages:7304-7310 